MAROLF, G. Advergaming and in-game advertising: an approach to the next generation of advertising. La Vergne, Tennessee: Lightning Source Inc., 2007.

\title{
Sandra Oliveira
}

Docente e Investigadora do Instituto Superior Miguel Torga, Coimbra, Portugal, Doutoranda em Ciências da Comunicação, Universidade do Minho, Braga - Portugal, e-mail: sandrafonso@gmail.com

Dificilmente poderíamos encontrar um livro sobre o assunto Advergaming tão completo. A actualidade do tema abordado é muito importante, já que cria uma plataforma de análise deste recente formato publicitário.

Gérald compila o tema de uma forma aprofundada e crítica. Auxilia-se de dados estatísticos e entrevistas em profundidade para conceber nesta obra a explicação exacta sobre o que é Advergaming e que benefícios trazem a uma marca publicitária.

A dissertação inicia-se com a questão centrada na forma como o formato é capaz de criar Brand Awareness. Parte também para a explicação de toda a carga histórica que envolve este tema, deixando aqui claro a parceria entre vídeo jogos e publicidade. Esta relação, segundo Marolf é a rampa de lançamento do Advergaming (capítulos 2 e 3 ).

O capítulo seguinte (4) dá-nos a conhecer a forma como um típico jogador se comporta e acima de tudo que tipo de atitude forma em relação a estes novos espaços publicitários. O apoio em estudos demográficos explica a razão pela qual o autor acredita no formato e no seu aparente sucesso. Se é certo que o estudo reflectido neste livro comporta um espaço temporal elevado (1980 a 2006) também será correcto dizer que mais estudos sobre a forma como o jogador age e reproduz a mensagem publicitária implícita ou explícita no formato deve ser tido em conta. $\mathrm{O}$ autor de facto não deixa de lado esta questão, mas vai enumerando de quando em vez a falta de estudos nesta área. O que pode por vezes deixar cair por terra algumas das ideias que recria na obra.

Marolf indica com precisão quais os objectivos do Advergaming para que possa ser "a powerful place to explore new ways of pushing consumer buttons" (p. 31). Criar e aumentar posição, conhecimento (Brand Awareness) e relação são alguns dos objectivos enumerados nesta secção do livro. De seguida, percebemos que há uma tentativa de completar as ideias ditas nos capítulos anteriores com o recurso aos resultados (positivos e negativos) conseguidos com a publicidade inserida em vídeo jogos. São invocados aqui estudos de caso e estudos de recepção e reacção de forma a explicar o uso destes espaços virtuais pelas marcas publicitárias e como conseguem chamar a atenção do jogador. 
O autor aproveita até a esta fase do livro para enquadrar o seu estudo e dar a conhecer as características principais do Advergaming. Podemos olhar para esta obra como um manual de boas práticas, onde o autor vai recheando o seu estudo com exemplos concretos e actuais. O mais interessante quiçá é a forma como complementa a visão real e proveitosa do uso de Advergaming com estudos e dados quantitativos, atestando o brilhantismo do formato. Pelo menos a tentativa de mostrar a forma como chega ao consumidor e os laços que o formato pode criar.

A partir daqui, a obra de Gérald Marolf divide-se em dois grandes temas. O capítulo 7 aborda o primeiro tema, logo após explicação da internet como plataforma publicitária. Assim, o Advergame surge como um dos formatos que, derivado do Advergaming, permite criar jogos publicitários. $\mathrm{Ou}$ seja, permite criar e passar mensagens publicitárias de uma marca. Este tipo pode ser jogado online ou descarregado para um computador, telemóvel, consola, etc. $\mathrm{O}$ autor aproveita neste momento para invocar uma técnica de marketing capaz de perpetuar a sensação de gratificação e divertimento que um jogador obtém de um Advergame, o Marketing Viral. Técnica muito usada na estratégia publicitária online, já que permite através de vários artifícios a partilha do jogo pela rede de "amigos" do jogador. Neste capítulo encontramos de forma elucidativa o tipo em demonstrativo (apresentação da marca no seio ambiente natural e pedido de interacção) e o associativo (associação da marca a um tipo de vida, estilo ou actividade). Angaria por consequência dois tipos limítrofes de Advergame: os Anti-Adgames, capazes de "become a real problem for the company who gets attacked" (p. 65) e os En-Game-ent, também chamados de Serious Games, capazes de afectar o comportamento e gerar acção para determinada campanha social ou evento social.

O segundo grande tipo (capítulo 8) capacita as marcas em criar espaços publicitários dentro de jogos. Aqui a relação com a indústria dos vídeo jogos é criada e acelera o realismo do cenário do jogo. Já que implementa as suas mensagens comerciais em quadros, outdoors, etc no ambiente do jogo. Falamos de In-Game Advertising, que indica exactamente publicidade dentro de um jogo. Marolf aponta grandes vantagens neste tipo, pois acredita que é o futuro da publicidade. Enumera razões de disponibilidade dedicada cada vez mais ao entretenimento via jogo por parte dos consumidores o que poderá ser uma plataforma capaz de passar mensagens publicitárias. O autor não é ingénuo ao afirmar que este tipo pode criar algumas desvantagens. Não ignora então a forma como alguns jogadores mais sensíveis reagem a este tipo de ocupação de espaço do seu jogo de eleição. E reafirma a coerência da inclusão da marca com o tipo/cenário/objectivo de um vídeo jogo. O capítulo termina com alusão a três tipos de In-Game Advertising (off-line games, multiplayer online games e massive multiplayer online games) acrescentando mais-valia ao segundo grande tipo da obra. $\mathrm{O}$ autor apoia-se também ao longo de vários capítulos, pois vai referenciando, de entrevistas que fez aos actores deste tipo de formatos (criadores, investigadores e $\mathrm{CEO}$ de grandes empresas)

Não sendo de todo o Santo Graaldo tema, o livro expõe de forma completa as tendências de um formato que se diz ser capaz de angariar a atenção já há muito desviada na publicidade de uma marca. Contudo, o autor não fica pela mera descrição dos benefícios dos formatos. Mune-se de áreas como estatística, psicologia e estratégia publicitária para atestar aquilo que ele acredita serem espaços privilegiados para a marcar impor a sua mensagem.

Marolf traz em relevo as vantagens do Advergaming, mas sem esquecer as suas desvantagens. Afirma convictamente que as últimas existem se o jogo for mal pensado. Nas palavras que usa, o autor eleva o formato ao pico da eficácia publicitária, enumerando com quase total certeza que a sua inclusão na estratégia publicitária de uma marca, traz e garante atenção das pessoas.

Este conceito veio criar uma nova forma de as marcas poderem chegar ao consumidor de forma informal, já que significa a inclusão de mensagens publicitárias nos conteúdos procurados pelos consumidores. Este tipo de publicidade tem forte aceitação e é considerada menos intrusiva pelo carácter de entretenimento fortemente associado ao jogo. Com estes factores reunidos, o efeito pode ser notoriamente conseguido criando no jogador sensações de imersão, por meio do entretenimento e comprometimento. O pedido de atenção feito ao consumidor é alcançado de forma impactante em detrimento daquilo que é pedido ao visionar, por exemplo um anúncio televisivo de 30 segundos. Os efeitos indicados podem vir a gerar significado e 
criar relação devido à quantidade de tempo que o consumidor é exposto à mensagem da marca. $\mathrm{O}$ autor explica na sua obra que é possível aliar ao tempo de divertimento interacção com o produto da marca, criando com toda a certeza retenção da imagem da marca e até no fundo atitude positiva para com ela (Brand Awareness).

Registe-se ainda, em jeito de complementaridade do estudo de Marolf, estudos que apontam para a eficácia positiva do uso deste tipo de formatos (WISE et al., 2008), onde encontramos indicação de que o uso cria vantagens no que diz respeito à relação entre marca e jogador. Ou também o estudo de Freitas (2007) que afirma que o uso deste tipo de Brand Entertainment é benéfico para a fixação e sensibilização da marca ou produto e que, no fundo, auxiliam as marcas a criarem fidelização e recordação posteriores.

\section{Referências}

FREITAS, D. Jogos eletrônicos como ferramentas de publicidade: conceitos, aplicações e perspectivas. In: SIMPÓSIO BRASILEIRODE GAMES-SBGAMES, 6., 2007, São Leopoldo. Anais... São Leopoldo: Unisinos, 2007. Disponívelem: <http://www.sbgames.org/papers/ sbgames07/artanddesign/full/ad9.pdf $>$. Acesso em: 28 jun. 2009.

WISE, K. et al. Enjoyment of advergames and brand attitudes: the impact of thematic relevance. Journal of Interactive Advertising, v. 9, n. 1, 2008. Disponível em: <http://www.jiad.org/article107>. Acesso em: 28 jun. 2009.

Recebido: 26/03/2011

Received: 03/26/2011

Aprovado: 26/05/2011

Approved: 05/26/2011 